\title{
WPŁYW REWITALIZACJI PRZESTRZENI KONSUMPCJI NA SPOŁECZNO-EKONOMICZNY ROZWÓJ POLSKICH MIAST
}

\section{Wprowadzenie $^{1}$}

Ostatnie dwie dekady to czas bardzo szybkich przemian przestrzeni konsumpcji w polskich miastach. Miały one istotny wpływ na ich rozwój zarówno w aspekcie ekonomicznym, jak i społecznym. Celem artykułu jest opis i analiza procesów rewitalizacji rynków i ulic handlowych w polskich miastach po roku 1999. Na podstawie przeprowadzonej analizy szukam odpowiedzi na pytanie, jak przeprowadzone modernizacje wpłynęły na społeczno-ekonomiczny rozwój polskich miast.

Przemiany przestrzeni konsumpcji pokazuję na przykładzie dwóch miast wojewódzkich: Białegostoku i Kielc. Miasta te mają wiele cech wspólnych uzasadniających dokonanie porównania, różniąc się równocześnie dynamiką i intensywnością zachodzących procesów. Zarówno cechy wspólne, jak i różnice umożliwiają wyodrębnienie determinant i skutków zachodzących przemian. Obydwa miasta są średniej wielkości (liczba mieszkańców Białegostoku w 2012 r. - około 295 tys., liczba mieszkańców Kielc w 2012 r. - około 201 tys. $)^{2}$, są stolicami województw położonych we wschodniej części Polski. Obydwa województwa zaliczane są do pięciu najsłabiej rozwiniętych województw w Polsce i z tego powodu w latach 2007-2013 korzystały z unijnego programu wyrównywania różnic rozwojowych - Programu „Rozwój Polski Wschodniej”3. Niski poziom rozwoju gospodarczego skutkuje niewielką liczbą zagranicznych inwestorów, co przekłada się na niewielki stopień zaawansowania

\footnotetext{
1 Artykuł jest fragmentem opracowania przygotowanego w ramach Badań Młodych Naukowców w 2014 r. (KES/BMN/10/14).

2 Bank Danych Lokalnych, Ludność wg miejsca zamieszkania, http://www.stat.gov.pl/bdl/app/dane podgrup.display?p_id=693454\&p_token=0.5318003590218723, dostęp 30.07.2013. W 1999 r. Białystok zamieszkiwało 288756 osób, w 2012 r. liczba mieszkańców wzrosła do 294 921; w 1999 r. Kielce zamieszkiwało 214242 osób, w 2012 r. liczba mieszkańców spadła do 200938.

3 Portal Funduszy Europejskich Rozwój Polski Wschodniej, http://www.polskawschodnia.gov.pl/WstepDoFunduszyEuropejskich/Strony/program.aspx, dostęp17.07.2013.
} 
procesów metropolitarnych. Pozwala to na wyodrębnienie lokalnej specyfiki przemian oraz opóźnia i spowalnia ten proces. Zarówno w przestrzeni śródmieścia Białegostoku, jak i Kielc w pierwszej dekadzie XXI w. zrewitalizowano główne ulice handlowe i rynki. Cechą charakterystyczną Białegostoku, odmienną od Kielc, jest przygraniczne położenie, które skutkuje m.in. dużą liczbą zagranicznych klientów przyjeżdżających do miasta na „weekendowe zakupy”. Wpływa to na dynamiczny rozwój infrastruktury handlowej miasta. Białystok jest dobrym przykładem średniej wielkości miasta, w którym jeszcze 10 lat temu cały handel miejski zasadzał się na działalności małych sklepów i targowisk miejskich, obecnie zaś koncentruje się głównie w kilku dużych centrach handlowych, licznych super- i hipermarketach. W Kielcach przekształcenia te miały znacznie powolniejszy i mniej intensywny przebieg. Tak różny kształt procesu przemian przestrzeni konsumpcji w dwóch miastach wojewódzkich, o porównywalnej liczbie ludności, porównywalnym poziomie rozwoju gospodarczego i zlokalizowanych w tej samej części kraju potwierdza zasadność analizy komparatystycznej.

Przemiany miejskich przestrzeni konsumpcji analizuję od 1999 r., czyli czasu wdrożenia reformy administracyjnej (1 stycznia 1999 r. $)^{4}$, na mocy której zmieniono strukturę administracji terytorialnej w Polsce. Miało to konsekwencje w postaci zmiany sposobu podejmowania decyzji dotyczących poszczególnych miast i województw, zwiększenia kompetencji władz samorządowych, zmiany granic i powierzchni poszczególnych województw, redukcji liczby miast wojewódzkich.

Miejska przestrzeń konsumpcji jest szczególnym rodzajem miejskiej przestrzeni publicznej, w literaturze przedmiotu definiowanej jako „fragment przestrzeni miejskiej, który - poprzez sposób swojego urządzenia oraz lokalizację w strukturze urbanistycznej - jest przeznaczony na potrzeby realizacji bezpośrednich kontaktów pomiędzy uczestnikami życia społecznego oraz inne potrzeby społeczne korzystających z niego zbiorowości, pozostając jednocześnie fizycznie dostępny dla wszystkich zainteresowanych osób. Fizyczna dostępność przestrzeni może być ograniczana czasowo z uwagi na kwestie bezpieczeństwa bądź sposób organizacji jej wykorzystania"s. Miejska przestrzeń konsumpcji jest określana w literaturze przedmiotu jako „obszar działań związanych ze społecznym bądź indywidualnym spożywaniem dóbr

4 Ustawy z dnia 5 czerwca 1998 r.: o samorządzie województwa (DzU nr 91, poz. 576), o administracji rządowej w województwie (DzU nr 91, poz. 577), o samorządzie powiatowym (DzU nr 91, poz. 578); ustawa z dnia 24 lipca 1998 r. o wprowadzeniu zasadniczego trójstopniowego podziału terytorialnego państwa (DzU nr 96, poz. 603 i nr 104, poz. 656); ustawa z dnia 24 lipca 1998 r. o zmianie niektórych ustaw określających kompetencje organów administracji publicznej - w związku z reformą ustrojową państwa (DzU nr 106, poz. 668).

5 P. Lorens, Definiowanie współczesnej przestrzeni publicznej, w: Problemy kształtowania przestrzeni publicznych, red. P. Lorens, J. Martyniuk-Pęczek, Wydawnictwo Urbanista, Gdańsk 2010, s. 10. 
i usług oraz z prostą i rozszerzoną reprodukcją zdolności do pracy"6. Odwołując się do ustaleń literatury przedmiotu, a równocześnie uwzględniając zakres tematyczny artykułu, zawężam znaczenie pojęcia miejskiej przestrzeni konsumpcji do galerii handlowych, rynków i głównych ulic handlowych zlokalizowanych w centralnych częściach miasta.

Opracowanie powstało na podstawie analizy wyników jakościowych badań terenowych, w ramach których posłużyłam się metodą wywiadu swobodnego ukierunkowanego. Wywiady prowadziłam od kwietnia do sierpnia 2014 r. z celowo wybranymi ekspertami z zakresu przemian przestrzeni konsumpcji w Kielcach i Białymstoku. Kryterium doboru rozmówców był zakres pełnionych przez nich funkcji zawodowych, a w kilku przypadkach pozazawodowych. W ten sposób wyodrębniłam trzy kategorie rozmówców: przedstawicieli władz miasta, przedstawicieli podmiotów gospodarczych związanych z przestrzenią konsumpcji oraz przedstawicieli organizacji i ruchów miejskich. W efekcie tak przyjętych zasad doboru rozmówców przeprowadziłam dwadzieścia sześć wywiadów. Zebrany materiał empiryczny poddałam analizie jakościowej. Informacje uzyskane od rozmówców zestawiam $\mathrm{z}$ wiedzą czerpaną z literatury przedmiotu oraz z dokumentów urzędowych.

Rozmówcy, prasa lokalna oraz informacje umieszczane na oficjalnych portalach internetowych urzędów miast określały realizowane przekształcenia terminem rewitalizacji. Jednak opisy zachodzących przemian i wskazywane pożądane konsekwencje realizowanych projektów wskazywały na infrastrukturalny charakter zmian, pomijający poszukiwanie rozwiązań dla najważniejszych społecznych problemów miasta. $\mathrm{Z}$ tego powodu uważam, że trafniejszym określeniem dla zrealizowanych przemian byłby termin „modernizacja” lub „przebudowa” aniżeli „rewitalizacja”, której ważnym aspektem jest rozwiązywanie społecznych problemów. Mimo to terminów „rewitalizacja” i „modernizacja” używam zamiennie, uzasadniając taką decyzję zastosowaną metodą badawczą. Osoby, z którymi rozmawiałam, używały określenia rewitalizacja, dlatego również zastosuję ten termin.

\section{Cel rewitalizacji rynków i ulic handlowych w Białymstoku i Kielcach w opiniach rozmówców}

Władze Białegostoku, mówiąc o założeniach rewitalizacji śródmieścia, podkreślały, że jej celem było stworzenie wyraźnego centrum miasta, placu miejskiego,

6 B. Jałowiecki, Społeczna przestrzeń metropolii, Wydawnictwo Naukowe Scholar, Warszawa 2000, s. 9. 
miejsca koncentrującego życie społeczne, kulturalne i rozrywkowe. Wskazując ten cel, urzędnicy podkreślali, że miasto było dotychczas pozbawione takiego miejsca ${ }^{7}$. Elementem rewitalizacji było również przekształcanie terenów pofabrycznych, zlokalizowanych w centrum miasta, $w$ galerie handlowe oraz przenoszenie produkcji przemysłowej z centrum miasta na jego obrzeża lub do Specjalnej Strefy Ekonomicznej zlokalizowanej poza miastem ${ }^{8}$.

Władze Kielc mówiły dużo i w szerokiej perspektywie o ogólnych założeniach rewitalizacji. W mieście tym podjęto decyzję, aby rozpocząć ją od ścisłego centrum, czyli m.in. rynku i ulicy Sienkiewicza, w kolejnych latach rozszerzając ją na osiedla mieszkaniowe oddalone od centrum, a także tereny poprzemysłowe i powojskowe. Taki sposób rewitalizacji stał się naturalną konsekwencją założeń przyjętych w strategii rozwoju miasta, zgodnie z którymi podstawą dobrobytu miasta ma być rozwój Targów Kielce, uczelni wyższych oraz ośrodka kulturalno-sportowego. Konsekwencją tych działań powinien być napływ zewnętrznych gości: klientów targów, studentów spoza Kielc oraz osób przyjeżdżających na imprezy kulturalne i sportowe, których "naturalną przestrzenią przebywania jest serce miasta", czyli jego centrum. W związku z taką strategią władze lokalne uznały, że miastu należy przywrócić jego historyczną postać, jego XVIII-XIX-wieczny charakter ${ }^{10}$, a dotychczasowy monofunkcyjny, czyli handlowy wymiar centrum miasta powinien ustąpić miejsca funkcjom kulturalnym, rozrywkowym oraz gastronomicznym. Podniesienie jakości przestrzeni śródmieścia i komfortu odczuwanego w trakcie korzystania $\mathrm{z}$ tej przestrzeni miało służyć zachęceniu mieszkańców do spędzania czasu wolnego w śródmieściu. Rewitalizacja śródmieścia miała stworzyć reprezentacyjną przestrzeń, a także podnieść konkurencyjność całego miasta.

\section{Przebieg rewitalizacji przestrzeni konsumpcji w Kielcach i w Białymstoku}

Przestrzeń Białegostoku i Kielc w ciągu pierwszej dekady XXI w. podlegała licznym rewitalizacjom, często, choć nie zawsze współfinansowanym $\mathrm{z}$ funduszy Unii Europejskiej. W badanych miastach przebudowy miały służyć różnie definiowanym celom i odbywały się w różnym porządku. W Białymstoku przebudowę śródmieścia

\footnotetext{
7 Wywiad 12.

8 Wywiady 12, 14.

9 Wywiad 2.

10 Wywiad 3.
} 
rozpoczęto od rynku, później modernizując przestrzeń ulicy Lipowej. W Kielcach proces ten przybrał odwrotną kolejność - rozpoczęto go od ulicy Sienkiewicza, zakończono przebudową rynku. Niezależnie od kolejności przemian, rozmówcy $\mathrm{z}$ obydwóch miast podkreślali przede wszystkim istotę przekształcenia rynku, opowiadając o niej wiele, a pomijając milczeniem lub krótkim komentarzem przebieg przebudowy głównych ulic handlowych.

\subsection{Rewitalizacja przestrzeni konsumpcji w Białymstoku}

Pierwszym zrealizowanym projektem rewitalizacyjnym w Białymstoku była rewitalizacja Rynku Kościuszki. Efektami tej zmiany szczycą się nie tylko władze miasta, ale również jego mieszkańcy. Właściwie każdy rozmówca pytany o najważniejszą zmianę, jaka zaszła w przestrzeni Białegostoku w ostatniej dekadzie, wskazywał rewitalizację Rynku Kościuszki.

Rynek Kościuszki po rewitalizacji otworzono w sierpniu 2009 r. ${ }^{11}$ Celem jego przekształcenia było stworzenie placu miejskiego nawiązującego do XVIII-wiecznych założeń urbanistycznych, stworzenie przestrzeni odpowiedniej dla organizacji uroczystości państwowych i kościelnych, przestrzeni usługowej, reprezentacyjnej i kulturalnej. W wyniku rewitalizacji miasto zyskało nie tylko prawdziwy plac miejski, ale również jednoznacznie wyznaczone centrum, którego wcześniej było pozbawione. Przed rewitalizacją nawet mieszkańcy miasta mieli trudności z jednoznacznym wskazaniem centrum miasta, nie było określone, czy znajduje się ono na rynku, ulicy Lipowej, czy np. przy Pałacu Branickich ${ }^{12}$.

W ramach rewitalizacji Rynku Kościuszki wprowadzono trzy zasadnicze zmiany. Po pierwsze, rynek, który dotychczas był bardzo ważnym węzłem komunikacyjnym dla transportu publicznego, ale też dla prywatnych samochodów, został wyłączony $\mathrm{z}$ ruchu samochodowego i przeznaczony tylko dla pieszych. Wzbudziło to protesty mieszkańców, obawiających się utrudnień w przejazdach przez centrum miasta. Komunikację miejską postanowiono poprowadzić wąskimi uliczkami okalającymi rynek. W związku z tym sprzeciw swój wyrazili mieszkańcy tych uliczek, obawiający się pogorszenia warunków mieszkania. Protestowali również działający w okolicy przedsiębiorcy, którzy argumentowali, że po likwidacji przystanków autobusowych zlokalizowanych na rynku spadnie liczba osób podróżujących przez centrum miasta, a tym samym liczba kupujących w ich sklepach. Drugą zmianą była likwidacja posadzonego w latach 70. XX w. na rynku zielonego skwerku. Wywołało to silny

\footnotetext{
11 Wywiad 14.

12 Wywiad 12.
} 
sprzeciw społeczny, mieszkańcy bronili miejskiej zieleni i rosnących tam cennych gatunków drzew. Władze miasta argumentowały jednak, że plac miejski nie jest parkiem, a parków w okolicy jest wiele. Co więcej, urzędnicy nie uważali rosnących drzew za cenne okazy, nazywali je „rachitycznymi krzaczkami”"13, w związku z czym skwerek został zlikwidowany, a pozostawiono jedynie wybrane drzewa. Uzyskaną w ten sposób przestrzeń wyłożono kostką brukową, zbudowano murki, postawiono ławki, fontanny i inne obiekty małej architektury. Co ciekawe, mimo że zamknięto ruch uliczny, nie zlikwidowano krawężnika oddzielającego plac od dawnej ulicy. Zwrócił na to uwagę jeden z rozmówców, sugerując, że było to spowodowane przewidywaną możliwością przywrócenia ruchu samochodowego na placu ${ }^{14}$. Trzecią ważną zmianą wprowadzoną na Rynku Kościuszki, która również wywołała sprzeciw i dyskusje przede wszystkim wśród działających na Rynku Kościuszki przedsiębiorców, było przeznaczenie miejskich lokali na tym placu na cele gastronomiczne. Wieloletni najemcy miejskich lokali na Rynku Kościuszki: Księgarnia Akcent oraz sklep z antykami Desa zostali zmuszeni do rozszerzenia swojej działalności o elementy gastronomiczne lub rezygnacji z wynajmu dotychczas użytkowanych lokali. Sklep Desa zrezygnował z działalności i przeniósł się do innego, należącego do prywatnego właściciela lokalu, Księgarnia Akcent wprowadziła do swojej oferty usługi gastronomiczne, zmieniając też nawę lokalu na Księgarnio-Kawiarnia Akcent ${ }^{15}$.

Władze Białegostoku zadbały również o rewitalizację otaczających rynek kamienic. Aby umożliwić współfinansowanie remontu kamienic z budżetu miasta, konserwator zabytków wpisał do rejestru zabytków pierzeje rynkowe, a miasto każdego roku przeznacza od kilkuset tysięcy do miliona złotych na remonty zabytkowych obiektów. W ten sposób co roku kilku właścicieli kamienic korzysta z pomocy finansowej miasta przeznaczonej na remont zabytkowych budynków ${ }^{16}$.

Przebudowa Rynku Kościuszki trwała od 2007 do 2009 r. Chociaż projekt został sfinansowany $z$ budżetu miasta, to możliwość finansowania innych modernizacji z funduszy unijnych odegrała tu ważna rolę, gdyż pozwoliła na przeznaczenie odpowiedniej kwoty z budżetu miasta na rewitalizację rynku.

Drugą ważną zmianą w przestrzeni śródmieścia Białegostoku była rewitalizacja ulicy Lipowej, która miała miejsce w latach 2011-2012. W jej wyniku poszerzono przestrzeń dla pieszych, zmieniono nawierzchnię chodników - wyłożono je granitowymi płytami, stworzono ścieżki rowerowe, a na zwężonej ulicy ograniczono ruch samochodów. Postawiono również elementy małej architektury: fontanny, rzeźby, ławki, zmieniono

\footnotetext{
13 Ibidem.

14 Wywiad 12

15 Wywiady 22 i 25.

16 Wywiad 25.
} 
oświetlenie oraz podświetlono najważniejsze zabytki. Rewitalizacja ulicy Lipowej miała na celu poprawę walorów estetycznych ulicy, nadanie „nowego wyrazu przestrzeni, nowej jakości wykonania materiałowego"17. Celem rewitalizacji było również nawiązanie do rozwiązań przyjętych na Rynku Kościuszki, stworzenie spójnej przestrzeni. Również przy ulicy Lipowej władze miasta chciały wynajmować lokale miejskie tylko w celach gastronomicznych. Okazało się, że nie ma chętnych przedsiębiorców do prowadzenia takiej działalności w tym miejscu, w związku z czym zrezygnowano $\mathrm{z}$ tych planów, trzymając się jednak zasady, że miejskie lokale nie są wynajmowane oddziałom telefonii komórkowych, bankom oraz salonom $\mathrm{z}$ sukniami ślubnymi ${ }^{18}$. Władze miasta planują w przyszłości wyłączyć ulicę Lipową z ruchu samochodowego, co ma dodatkowo podnieść jej atrakcyjność jako miejsca spotkań mieszkańców.

Pomysł, aby centrum miasta stanowiło ośrodek życia towarzyskiego, aby koncentrowało lokale gastronomiczne spotyka się ze sprzeciwem okolicznych mieszkańców. Wspólnoty mieszkaniowe zamieszkujące budynki, w których na parterze miałby być umieszczony lokal gastronomiczny, nie wyrażają na to zgody. Jeszcze większy sprzeciw wywołują próby najemców lokali, aby uzyskać koncesję na sprzedaż alkoholu. Mieszkańcy nie chcą mieć w sąsiedztwie lokali generujących hałas, protestują więc przeciw każdej zmianie, która mogłaby zakłócić komfort mieszkania w danej okolicy ${ }^{19}$.

W Białymstoku rozmówcy wielokrotnie zastanawiali się, jakie funkcje powinno pełnić centrum miasta, jakie funkcje można uznać za centrotwórcze ${ }^{20}$, jakie są najbardziej pożądane funkcje miastotwórcze ${ }^{21}$ oraz jakie obiekty można nazwać centroi miastotwórczymi. Prezydent miasta wskazał, że „są to usługi związane z uprzyjemnianiem życia mieszkańców oraz zaspokajaniem ich podstawowych potrzeb, czyli usługi związane z zaspokajaniem potrzeb handlowych, kulturalnych, gastronomicznych"22.

Równocześnie prezydent wskazał, że zamysłem władz miasta było lokalizowanie usług handlowych w centrach handlowych w dążeniu do utworzenia w śródmieściu strefy gastronomiczno-rozrywkowej, zauważając jednak, że żaden plan i wizja władz miejskich nie jest w stanie wpłynąć ostatecznie na decyzje podejmowane przez przedsiębiorców oraz preferencje mieszkańców. Dowodem na prawdziwość tego stwierdzenia jest sytuacja ulicy Lipowej, gdzie zaplanowano funkcje centrotwórcze, a gdzie coraz częściej są lokalizowane sklepy spożywcze. Takie lokale są potrzebne okolicznym mieszkańcom, trudno je jednak nazwać centrotwórczymi²3.

\footnotetext{
17 Wywiad 14.

18 Wywiad 25.

19 Wywiad 13.

20 Ibidem.

21 Wywiad 25.

22 Wywiad 13.

23 Wywiad 25.
} 


\subsection{Rewitalizacja przestrzeni konsumpcji w Kielcach}

Pierwszą zmodernizowaną przestrzenią w śródmieściu Kielc była ulica Sienkiewicza. Jej przebudowa trwała od 2001 do 2007 r. i była sześcioetapowa. Przebudowa około 40\% długości ulicy była finansowana wyłącznie ze środków własnych miasta. Po wstąpieniu Polski do Unii Europejskiej zmodernizowano blisko 60\% ulicy przy wsparciu środków z Europejskiego Funduszu Rozwoju Regionalnego w ramach Zintegrowanego Programu Operacyjnego Rozwoju Regionalnego na lata 2004-2006. Dofinansowanie unijne wynosiło nieco ponad $11 \mathrm{mln}$ zł, z budżetu państwa Kielce dostały dofinansowanie w wysokości 1,4 mln zł, 2,8 mln zł dodały z własnych środków ${ }^{24}$.

W ramach rewitalizacji wymieniono nawierzchnię na całej długości ulicy, w miejsce asfaltu położono granitową kostkę, wymieniono podziemną infrastrukturę techniczną, w donicach posadzono egzotyczne kwiaty, wprowadzono elementy małej architektury oraz stylizowane latarnie ${ }^{25}$. Wzdłuż ulicy stworzono również dwa place - Plac Artystów i tzw. Plac Czterech Wieszczów (plac nie ma jeszcze oficjalnej nazwy) przeznaczone do organizacji różnych wydarzeń kulturalnych oraz na spotkania dla kielczan $^{26}$. Ulica Sienkiewicza od wielu lat jest zamknięta dla ruchu samochodowego, mieszkańcy i władze miasta przyzwyczaili się już do tego, nie ma więc żadnej dyskusji na temat zasadności takiego stanu. Deklarowanym w oficjalnych materiałach urzędu miasta celem rewitalizacji było „podniesienie atrakcyjności przestrzennej i funkcjonalnej, a zarazem społeczno-gospodarczej ulicy Sienkiewicza, a w konsekwencji zachowanie i wzmocnienie roli Kielc jako krajowego ośrodka wzrostu”27.

Drugą najbardziej zauważalną zmianą w centrum Kielc było przywrócenie historycznej formy rynku. Przemiana ta, w języku urzędników nazywana „przebudową płyty rynku”, stała się jednym z sześciu etapów projektu „Rewitalizacja zabytkowego Śródmieścia Kielc" i została sfinansowana ze środków Europejskiego Funduszu Rozwoju Regionalnego, w ramach Regionalnego Programu Operacyjnego Województwa Świętokrzyskiego na lata 2007-2013. Całkowita wartość projektu wynosiła $57 \mathrm{mln}$ zł, z czego kwota dofinansowania ze środków europejskich wynosiła $44 \mathrm{mln}$ zł, co stanowiło $76,6 \%$ całkowitej wartości projektu ${ }^{28}$.

${ }^{24}$ Oficjalna strona urzędu miasta Kielce, http://www.um.kielce.pl/fundusze_unijne/sienk, dostęp 25.09.2014; A. Iwanowska-Kędzierska, Szykowne śródmieście „,Biuletyn SPORR” 2(10), 2007, http://www.rpo-swietokrzyskie.pl/swietokrzyskie-zporr/zdjecia_art/2483/BiuletynZPORR_10.pdf, s. 15, dostęp 26.09.2014.

${ }^{25}$ Oficjalna strona urzędu miasta Kielce, http://www.um.kielce.pl/fundusze_unijne/, dostęp 25.09.2014.

26 Wywiad 3.

${ }^{27}$ Oficjalna strona internetowa Urzędu miasta Kielce, http://www.um.kielce.pl/fundusze_unijne/sienk, dostęp 25.09.2014.

${ }_{28}$ Oficjalna strona internetowa Urzędu miasta Kielce, http://www.um.kielce.pl/fundusze_unijne/srodmiescie-1, dostęp 25.09.2014. 
Rewitalizacja kieleckiego rynku zmieniła diametralnie charakter tej przestrzeni. Od II wojny światowej do 2008 r. na środku kieleckiego rynku zlokalizowany był wybudowany przez Niemców zbiornik przeciwpożarowy zaadaptowany na fontannę, wokół której rosły kwiaty i drzewa, porozstawiano ławeczki. Jednak plac ten był otoczony ruchliwym rondem, które nie tylko utrudniało dojście do niego, ale też niwelowało przyjemność ze spędzania tam czasu. Zaniedbany skwer nie był miejscem popularnym wśród kielczan, a jedynymi jego użytkownikami byli konsumenci alkoholu. Rynek, podobnie jak w Białymstoku, pełnił rolę wyłącznie komunikacyjną.

W latach 2008-2011 władze miasta przeprowadziły projekt przebudowy rynku, w którego ramach wycięto drzewa, zlikwidowano fontannę i rondo, zminimalizowano ruch uliczny. Powierzchnię placu pokryto nawiązującą do czasów średniowiecza kostką brukową. Stworzono klomby z drzewami, ławeczki i fontanny, a na środku postawiono pręgierz i pompę wodną. Ideą przewodnią przebudowy było stworzenie rynku na wzór średniowiecznego placu ${ }^{29}$. Podobnie jak w Białymstoku mieszkańcy protestowali przeciwko wycinaniu zieleni miejskiej oraz zamykaniu ruchu samochodowego. Argumenty używane przez niezadowolonych mieszkańców były podobne do tych, które pojawiły się w Białymstoku. O ile jednak białostoczanie protestowali przed i w trakcie przebudowy rynku, akceptując go, gdy rewitalizacja się skończyła, kielczanie po otwarciu nowej płyty rynku w czerwcu 2011 r. dalej go krytykowali, przede wszystkim za brak zieleni, brak cienia, za małą liczbę ławek oraz panującą monotonię ${ }^{30}$.

Władze miasta deklarują, że od samego początku były świadome, że płytę rynku należy zagospodarować i uatrakcyjnić. W związku z krytyką mieszkańców podjęto działania służące pobudzeniu na niej życia, umożliwieniu różnych aktywności oraz odparciu zarzutów o betonowanie miasta. Wprowadzając zmiany na rynku, urzędnicy musieli dostosować się do wymogu Unii Europejskiej nienaruszania płyty rynku przez 5 lat ${ }^{31}$. W związku z tym zespół kieleckich architektów we współpracy z urzędem miasta oraz w konsultacji z mieszkańcami wypracowali projekt „salonu miejskiego"32, czyli strefy rekreacyjno-wypoczynkowej. Na rynku ustawiono donice z drzewami, leżaki, dodatkowe ławki, fotele, hamaki, trampolinę ${ }^{33}$. Cechą charakterystyczną „salonu” kieleckiego jest to, że stworzono go z przenośnych, nieprzytwierdzonych

\footnotetext{
${ }^{29}$ Jeden z urzędników mówił o średniowiecznym charakterze miasta, inny o przełomie XIX i XX w.

30 Wywiad 2.

${ }^{31}$ Ibidem.

32 Pojęcia „salon miejski” używa Bohdan Jałowiecki - w prowadzonych przez niego badaniach percepcji przestrzeni Warszawy w 1980 r. badani określali Stare Miasto i Łazienki tym mianem. Za: B. Jałowiecki, Percepcja przestrzeni Warszawy, „Studia Regionalne i Lokalne” nr 2(2), 2000, s. 86.

${ }_{33}$ P. Burda, Hamaki już kołyszą. Uroczyście otwarto salon miejski na kieleckim rynku, 4.08.2013, http:// www.echodnia.eu/apps/pbcs.dll/article?AID=/20130804/POWIAT0104/130809559, dostęp 5.11.13.
} 
do podłoża modułów - mebli. Dzięki temu dostosowano się do unijnego wymogu nieingerowania w płytę rynku, równocześnie tworząc możliwość wprowadzania modyfikacji w ustawieniu modułów, a także dostawiania nowych mebli ${ }^{34} \mathrm{w}$ razie zaistnienia takiej potrzeby.

W ramach prowadzonych prac rewitalizacyjnych urząd miejski sfinansował remonty elewacji kamienic będących własnością miasta. Starając się zachęcić prywatnych właścicieli budynków do odnawiania elewacji swoich nieruchomości, wprowadzono trzyletnie ulgi w podatku od nieruchomości ${ }^{35}$ przeznaczone dla osób, które wyremontowały kamienice. Są również środki unijne, z których mogą skorzystać właściciele chcący wyremontować swoje nieruchomości. Chociaż zainteresowanie zdobywaniem tych funduszy było niewielkie, władze miasta zauważały trend rosnący ${ }^{36}$. Inny rozmówca zwracał z kolei uwagę na biurokrację związaną z ubieganiem się o środki unijne, $\mathrm{z}$ którego to powodu właściciele kamienic często wolą remontować je ze środków własnych ${ }^{37}$. Ten sam rozmówca stwierdził, że mieszkańcy podejmują inicjatywę i rozpoczynają remonty mniej więcej 3 lata po tym, jak urząd miasta zakończy swoje działania rewitalizacyjne.

Przemianie infrastruktury śródmieścia, ograniczeniu ruchu samochodowego $\mathrm{w}$ tej przestrzeni towarzyszyć miały zmiany funkcjonalne śródmieścia. Przedstawiciele władz miejskich uważają, że monofunkcyjny - handlowy charakter śródmieścia nie jest korzystny dla miasta i jego mieszkańców. Ich zdaniem funkcja handlowa musi ulec redukcji, a oferowany asortyment produktów - specjalizacji. Równocześnie powinny być rozwijane funkcje kulturalne, rozrywkowe i gastronomiczne. Tylko takie wielofunkcyjne śródmieście może być atrakcyjne dla mieszkańców, gości targowych i turystów.

\section{Ograniczenie ruchu samochodowego w śródmieściu jako ważny element rewitalizacji}

Jednym z najważniejszych działań zmieniających przestrzeń publiczną zarówno w Białymstoku, jak i w Kielcach było ograniczenie ruchu samochodowego w śródmieściu.

\footnotetext{
34 Wywiad 4.

35 Wywiad 2; D. Wojnowska, UM Kielce, Projektowe ujęcie rewitalizacji w Gminie Kielce przy wsparciu funduszy strukturalnych $w$ latach 2004-2013, http://irm.krakow.pl/uploadUser/file/II_A_Lokalne\%20Programy\%20Rewitalizacji\%20jako\%20narzedzia\%20odnowy\%20miast/A4_DWojnowska_Projektowe_ujecie_rewitalizacji.pdf, dostęp 29.09.2014.

36 Wywiad 3.

37 Wywiad 2.
} 
Było to równocześnie jedno z działań budzących najwięcej społecznych wątpliwości, nierzadko konfliktów i protestów. W Białymstoku, podobnie jak w Kielcach rynek był bardzo ważnym punktem komunikacyjnym, przebiegał przez niego ogólnomiejski ruch tranzytowy. W wyniku rewitalizacji został on ograniczony do niezbędnego minimum, co znaczy, że mogą tam wjeżdżać tylko samochody dostawcze oraz mieszkańcy. Białostocki rynek przecina na pół ruchliwa ulica Sienkiewicza, nie zdecydowano się na realizację planu wybudowania podziemnego tunelu i likwidacji ruchu naziemnego. Ulicę Lipową natomiast zwężono, ruch samochodowy został więc ograniczony i spowolniony, ale nie zlikwidowano go, pozostawiając tę zmianę na przyszłość. W Kielcach w ramach rewitalizacji śródmieścia władze miejskie zdecydowały się na ograniczenie lub zupełne wyeliminowanie ruchu samochodowego na wybranych ulicach. Taka zmiana, choć budząca wiele kontrowersji, zmniejszyła hałas i zanieczyszczenie śródmieścia, pozwoliła też usunąć chaotycznie parkowane na chodnikach samochody. Ulica Sienkiewicza od początku XXI w. jest deptakiem.

Likwidacja ruchu samochodowego miała poprawić jakość przestrzeni publicznych, zachęcając w ten sposób mieszkańców Kielc do odpoczywania w śródmieściu ${ }^{38}$. Urzędnicy miejscy podkreślali, że „Kielce są ładnym miastem, śródmieście mamy piękne, tylko było zabrudzone, zakurzone, rozjechane przez samochody [...] brud, smród, wszystko zdewastowane, no bo przez lata nikt tu nie inwestował, można się było zabić, idąc chodnikiem, o ile nie był zajęty przez samochód"39.

Zamknięciu ruchu samochodowego w śródmieściu Kielc towarzyszyło stworzenie systemu parkingów okalających śródmieście. Ideą takiego rozwiązania było umożliwienie mieszkańcom dojazdu do śródmieścia i zagwarantowanie bezpiecznych miejsc parkingowych zlokalizowanych w bezpośrednim sąsiedztwie śródmieścia ${ }^{40}$. Część parkingów już wybudowano, część pozostaje nadal w planach. Parkingi są płatne i z tego powodu wielu kielczan nie chce z nich korzystać. Do śródmieścia, do ulicy Sienkiewicza, można również dojechać komunikacją publiczną.

\section{Partycypacja społeczna w kształtowaniu zachodzących zmian}

Z rozmów przeprowadzonych w Białymstoku, zarówno z władzami miasta, jak i z przedstawicielami organizacji miejskich, wyłonił się obraz mieszkańców o biernej

\footnotetext{
38 Wywiad 2.

39 Ibidem.

40 Ibidem.
} 
postawie, niezabiegających o możliwość udziału w podejmowaniu decyzji o kształcie przeobrażeń miasta i niezainteresowanych jego przemianami. Równocześnie rozmówcy mówili o władzach miasta niezachęcających mieszkańców do aktywności obywatelskiej, sceptycznych wobec idei współrządzenia. Sami rządzący miastem krytycznie wyrażali się na temat zasadności angażowania mieszkańców w podejmowanie decyzji ${ }^{41}$. Mimo to w ciągu ostatnich 5-10 lat powstało kilka organizacji próbujących wpływać na przemiany przestrzeni miasta. Jednak współpraca $z$ władzami miasta nie zawsze układa się harmonijnie, a rządzący skarżą się na roszczeniową postawę tych organizacji, na to, że wyłącznie krytykują, nie proponując lepszych rozwiązań i nie chcąc zauważyć pozytywnych zmian i działań podejmowanych przez rządzących.

Rewitalizacja śródmieścia Białegostoku odbywała się bez konsultacji z mieszkańcami. Według relacji rozmówców miejska pracownia architektoniczna wypracowała założenia co do przyszłego kształtu śródmieścia, a następnie zleciła realizację projektu grupie specjalistów ${ }^{42}$. Inny rozmówca wspomniał, że projekt rynku był prezentowany publicznie, co spowodowało głośną debatę, również na łamach prasy lokalnej, na temat zasadności wycinania zielonego skweru oraz ograniczania ruchu samochodowego ${ }^{43}$. Także zmiany przeznaczenia lokali komunalnych na rynku spowodowały niezadowolenie i protesty mieszkańców, których interesy były naruszane, nie dochodziło jednak do zaangażowania szerszych grup społecznych.

Rewitalizacja Kielc i zmiany z nią związane przyczyniły się do aktywizacji różnych organizacji miejskich. Urzędnicy miejscy zauważali, że społeczność kielecka bardzo się uaktywniła, że pojawiają się coraz częściej pojedyncze osoby, albo różnego rodzaju organizacje pozarządowe, które interesują się przemianami miasta i chcą na nie wpływać. Równocześnie jeden $\mathrm{z}$ urzędników podkreślał, że urząd miasta chętnie bierze pod uwagę opinie mieszkańców, pod warunkiem, że są to konstruktywne uwagi, które równocześnie nie blokują realizacji inwestycji ${ }^{44}$. Rozmówca zwrócił uwagę, że organizacjom miejskim często wydaje się, że tylko ich wizja rozwoju miasta jest poprawna i w związku z tym nie akceptują innych rozwiązań. Urzędnik skrytykował też nadmierną koncentrację organizacji miejskich na kwestiach drzewostanu i innych zagadnieniach ekologicznych. Przyznał, że jego zdaniem niemożliwa jest realizacja inwestycji bez redukowania zieleni miejskiej oraz że nie można stawiać dobra ekologii ponad interesy mieszkańców miasta. Równocześnie dodał, że wycinaniu drzew towarzyszą nowe nasadzenia w innych miejscach, więc niesprawiedliwe jest oskarżanie władz miasta o betonowanie miasta. Przedstawiciele urzędu

\footnotetext{
41 Wywiad 25

42 Ibidem 25.

${ }^{43}$ Wywiad 14

44 Wywiad 3.
} 
miasta, podobnie jak urzędnicy z Białegostoku, skarżyli się na roszczeniową postawę organizacji miejskich, rzekomo niemających pomysłów na zmiany, a blokujących wszystkie projekty urzędu miasta. Urzędnicy miejscy w Kielcach mimo krytycznych uwag pod adresem organizacji miejskich $\mathrm{z}$ uznaniem wypowiadali się na temat wiedzy i kompetencji jednej z nich, a mianowicie Stowarzyszenia Kieleckie Inwestycje.

Jednak na początku rewitalizacji miasta organizacje miejskie nie były tak aktywne i nie upominały się o możliwość wpływania na kształt rewitalizacji. Nie były organizowane konsultacje społeczne, a urzędnik miejski tłumaczył ich brak małym doświadczeniem władz miasta i niewiedzą co do tego, że swoje decyzje powinno się skonfrontować z opinią mieszkańców. Rozmówca mówił: „my się też trochę uczyliśmy, wie Pani, jak robiono rynek, nie było konsultacji co do drobiazgów. Teraz już wiemy, że jak robimy przestrzeń publiczną, to żeby to dobrze wyszło, musimy do bólu skonsultować każdy szczegół”"45.

Wypowiedź ta równocześnie wskazuje na stosunek urzędnika do konsultacji społecznych, postrzeganych raczej jako zło konieczne, a nie jako źródło ciekawych pomysłów i konstruktywnej krytyki, element procesu, który trzeba zrealizować, aby uzyskać legitymizację swojej decyzji i zapobiec późniejszym protestom. Inny rozmówca zwrócił też uwagę na czas, który trzeba poświęcić na prowadzenie konsultacji społecznych, a który w przypadku projektów realizowanych przy wsparciu środków unijnych jest ograniczony ze względu na ramy czasowe wyznaczone na realizację projektu, oraz terminy, kiedy można ubiegać się o dofinansowanie. Powoduje to konieczność sprawnego prowadzenia konsultacji społecznych.

Ponieważ po wycięciu zieleni na kieleckim rynku różne środowiska miejskie coraz głośniej oskarżały władze lokalne o betonowanie miasta i stworzenie monotonnej „patelni”" ${ }^{\text {, }}$ urzędnicy postanowili urządzić na nim we współpracy z mieszkańcami „salon miejski”. Zorganizowano konsultacje społeczne na temat pożądanego wyglądu i funkcji pełnionych przez „salon”. Konsultacje prowadzono przez jeden dzień na rynku oraz trzy tygodnie w internecie, w ich ramach mieszkańcy mogli spośród przygotowanych propozycji zagospodarowania rynku wskazać ich zdaniem najlepsze. Nie pozwolono im jednak na przedstawienie własnych koncepcji na temat zagospodarowania rynku, nie dopuszczono również możliwości odrzucenia przygotowanych wcześniej planów. Taka forma konsultacji pozwoliła zrealizować szybko i sprawnie projekt - od momentu konsultacji do zakończenia stawiania na rynku „salonu miejskiego" minęły cztery miesiące. Jednakże sposób zorganizowania i przebieg konsultacji, którymi władze miasta Kielce się szczycą, a w których

\footnotetext{
45 Wywiad 2.

${ }^{46}$ Ibidem.
} 
tylko pozornie pozwolono kielczanom wyrazić swoje preferencje, wygląda na pewnego rodzaju fikcję i tworzenie pozorów angażowania społeczności w procesy decyzyjne. Również wynik tak przeprowadzonych konsultacji nie był zaskakujący, większość mieszkańców opowiedziała się „za zazielenieniem” przestrzeni runku.

Zanim zaczęto rewitalizację Kielc, skonsultowano z mieszkańcami zaplanowane przekształcenia. W 2004 r. przeprowadzono badanie ankietowe na próbie 700 dobranych losowo osób i zapytano ich o poparcie lub negację dla planowanych inwestycji $^{47}$. Najwięcej zwolenników miał plan przebudowy ulicy Sienkiewicza - 93\% ankietowanych kielczan popierało tę inwestycję. Inne plany zmian w centrum, takie jak przebudowa rynku czy zamknięcie śródmieścia dla ruchu kołowego, miały powyżej $60 \%$ poparcia. Około $20 \%$ badanych kielczan było przeciwnych tym dwóm zmianom. W badaniach pytano o poparcie dla poszczególnych zmian, które co do zasady stanowiły obietnicę poprawy infrastruktury miejskiej, nie dziwi więc ich akceptacja. Nie pytano jednak o szczegóły, o to, jak mieszkańcy chcieliby dokonać tych zmian ${ }^{48}$, co w późniejszym okresie, po zrealizowaniu planów przebudowy zaowocowało społecznym niezadowoleniem. W badaniu ankietowani zwracali uwagę na problem niedostatecznego informowania mieszkańców o planowanych inwestycjach. Na zakończenie raportu jego autorka zamieściła pouczenie na temat zasadności informowania mieszkańców o planowanych w mieście zmianach oraz o korzyściach płynących z pytania mieszkańców o opinie i wsłuchiwania się w ich potrzeby oraz pomysły ${ }^{49}$. W tym samym roku przeprowadzono również inne badanie na temat planowanych w mieście inwestycji, ich zasadności, kosztów oraz kolejności, w jakiej powinny być realizowane. W badaniu pytano mieszkańców o wizję i pomysły na rozwój miasta. Badanie zostało przeprowadzone przy zastosowaniu techniki zogniskowanych wywiadów grupowych wśród dziesięciu jedenastoosobowych grup dyskusyjnych dobranych według kryterium wieku i statusu społecznego ${ }^{50}$.

47 J. Kowalik, Fundacja Rozwoju Demokracji Lokalnej, Zmieniamy nasze miasto. Raport z konsultacji programu rewitalizacji Miasta z mieszkańcami, Kielce 2004, http://www.rewitalizacja3.kielce.eu/data/Pliki/28_9_ Zmieniamy_nasze_Miasto_-_Raport_z_konsultacji_programu_rewitalizacji_Miasta.pdf, s. 9, 11, 13, dostęp 29.09.2014. „Badaniami sondażowymi objęto ponad 700 osób, losowo dobranych spośród mieszkańców miasta. Próba badawcza licząca 600 osób została dobrana techniką doboru warstwowego z alokacją proporcjonalną w oparciu o trzy zmienne - płci, wieku i wykształcenia. Dodatkową grupę stanowiły osoby, które wyraziły chęć zaopiniowania planowanych działań, gdyż sprawy przyszłości Miasta są dla nich ważne. Wzięły one udział w badaniu na zasadzie doboru celowego - 50 spośród środowisk opiniotwórczych w naszym mieście oraz 50 spośród studentów uczelni wyższych naszego miasta oraz kilka osób wypełniających ankietę internetową", za: ibidem, s. 4.

48 Ibidem.

49 Ibidem, s. 31.

${ }^{50}$ J. Kowalik, Fundacja Rozwoju Demokracji Lokalnej, Kielce - moje Miasto. Priorytety inwestycyjne w Mieście w ocenie mieszkańców, Kielce 2004, http://www.rewitalizacja3.kielce.eu/data/Pliki/27_8_Kielce-moje_Miasto.doc.pdf, dostęp 29.09.2014. 


\section{Wpływ rewitalizacji przestrzeni konsumpcji na społeczno- -ekonomiczny rozwój badanych miast}

Należy podkreślić, że przebieg rewitalizacji i wprowadzone zmiany były w dwóch badanych miastach porównywalne. Zamknięto ruch samochodowy na rynkach, wycięto posadzone w latach 70 . XX w. skwerki, następnie wybrukowano powierzchnię rynku i głównej ulicy handlowej, na koniec stawiając różne elementy małej architektury. Zarówno w Białymstoku, jak i w Kielcach rozmówcy wskazywali wielokrotnie istotę przeprowadzonych przekształceń rynków, podkreślając, że były to najważniejsze zmiany w mieście, pomijając milczeniem rewitalizacje ulic handlowych. Dokonane rewitalizacje polegały nie tylko na kosmetycznych zmianach estetyki, na „odświeżeniu wizerunku”, były to gruntowne przebudowy całej zastanej infrastruktury, próba powrotu do historycznego kształtu śródmieść. Równocześnie były to zmiany budzące wiele dyskusji, protestów i sprzeciwu społecznego, które po zakończeniu, w opinii moich rozmówców, zyskały akceptację mieszkańców badanych miast.

Mimo że przeprowadzone zmiany były podobne, władze miast przypisywały im różne znaczenie. W Białymstoku bardzo podkreślano potrzebę stworzenia centrum miasta, placu miejskiego, miejsca spotkań mieszkańców. W Kielcach podkreślano przede wszystkim potrzebę powrotu do historycznej formy rynku, stworzenia estetycznej, atrakcyjnej i reprezentacyjnej przestrzeni. Myślę, że takie różnice w narracji wynikały z zastanych uwarunkowań. Rynki w obydwóch miastach pełniły ważne funkcje komunikacyjne, równocześnie nie będąc miejscem życia towarzyskiego i społecznego miasta. Jednak w Kielcach takie funkcje pełniła, wyłączona $\mathrm{z}$ ruchu samochodowego na początku XXI w., ulica Sienkiewicza, która była niezaprzeczalną osią życia towarzyskiego, handlowego, reprezentacyjnym deptakiem. Białystok nie posiadał wyłączonej z ruchu samochodowego przestrzeni i z tego powodu stworzenie takiego miejsca stało się priorytetem władz miasta.

Wszyscy rozmówcy w Białymstoku podkreślali, jak ważną zmianą była rewitalizacja rynku. Jej niezaprzeczalnym i najlepiej widocznym efektem była zmiana sposobu spędzania wolnego czasu przez białostocczan. Jeden z rozmówców podkreślał, że kiedyś rynek był przestrzenią, przez którą mieszkańcy „przemykali” w drodze do celu, nie zatrzymując się na dłużej, gdyż nie było po co. Inny rozmówca zauważył, że dawniej białostocczanie na spotkania umawiali się w konkretnym lokalu, po rewitalizacji zaczęli umawiać się na rynku, aby pospacerować, a gdy się zmęczą, usiąść $\mathrm{w}$ jednej $\mathrm{z}$ wielu restauracji. Jeszcze inny rozmówca następująco charakteryzował motywacje, dla których mieszkańcy chcą spędzać czas w przestrzeni rynku: „społeczeństwo akceptuje to, liczne wystawy i przede wszystkim tłumne przychodzenie 
tam, bo ludzie korzystają z tego. Tam są cykliczne imprezy i widać, że ci ludzie przychodzą, to nie jest przestrzeń martwa, no może zimą ona czasem jest martwa, ale bywały również i ślizgawki zimą, czy są jakieś jarmarki okolicznościowe: przedświąteczne, noworoczne czy wielkanocne. A latem to jest cały szereg imprez, czasami dzień po dniu, i koncertów, i widać ludzi, którzy tu przychodzą dość tłumnie" ${ }^{1}$.

W Kielcach również opowiadano o znaczeniu zrewitalizowanego rynku jako miejscu spotkań mieszkańców, zmiana ta jednak nie wysuwała się tak wyraźnie na pierwszy plan, jak miało to miejsce w Białymstoku. Podkreślano natomiast potrzebę nadania rynkowi nowej, reprezentacyjnej i atrakcyjnej dla zewnętrznych gości formy ze względu na targowy charakter miasta. Zgodnie z relacją moich rozmówców zarówno w Białymstoku, jak i w Kielcach osoby odwiedzające te miasta, a nieznające ich przed rewitalizacją, nazywają ich śródmieścia starówkami. Można to uznać za sukces polityki odtwarzania historycznego charakteru tych przestrzeni, niezależnie od tego, że nie ma porozumienia wśród rządzących Kielcami, czy odtworzono krajobraz średniowieczny, czy XVIII-XIX-wieczny.

Niezaprzeczalne korzyści dla miasta i jego mieszkańców wynikały z faktu, że wiele z projektów rewitalizacji w Kielcach było wykonane przez kieleckie przedsiębiorstwa. Nie tylko wzmocniono pozycję rynkową kieleckich przedsiębiorców, stworzono nowe miejsca pracy dla osób $\mathrm{z}$ regionu, ale również miasto zapewniło sobie zwiększone wpływy do budżetu z tytułu podatku dochodowego od osób fizycznych i od osób prawnych ${ }^{52}$. Jeden $\mathrm{z}$ kieleckich urzędników przyznał, że można zaobserwować pozytywny wpływ rewitalizacji na rozwój gospodarczy miasta, choć jest on słabiej zauważalny i wolniejszy niż prognozowały władze miasta ${ }^{53}$.

Ciekawą kwestią jest dostępność informacji dotyczących przeprowadzonych rewitalizacji. Na temat projektów finansowanych $\mathrm{z}$ funduszy europejskich informacje znajdowałam bez problemu na stronach internetowych urzędów miast. Ze zdziwieniem jednak odkryłam, że na stronach internetowych urzędów miast nie ma informacji na temat zmian finansowanych $\mathrm{z}$ funduszy własnych miasta, lakoniczne artykuły dotyczące tego tematu znajdowałam na różnych portalach samorządowych. Sytuacja dziwi, gdyż mowa tu o najważniejszych zrealizowanych projektach: przebudowie Rynku Kościuszki, przebudowie ulicy Lipowej w Białymstoku oraz przebudowie dużej części ulicy Sienkiewicza w Kielcach. Również w rozmowach z urzędnikami miejskimi nie poinformowano mnie, że zmiany te były finansowane $z$ budżetu miasta, a nie z funduszy unijnych.

\footnotetext{
51 Wywiad 14.

52 Wywiad 3.

${ }^{53}$ Ibidem.
} 


\section{Zakończenie}

Wpływ przemian przestrzeni konsumpcji na społeczno-gospodarczy rozwój miast można rozpatrywać w kategoriach krótko- i długoterminowych. Oceniając go, należy mieć na uwadze, że część konsekwencji będzie miała miejsce w przyszłości. Od momentu przemian minęło zaledwie kilka lat, na co zwrócił uwagę jeden $\mathrm{z}$ urzędników miejskich. Wskazał on, że efekty rewitalizacji można oceniać dopiero po upływie 25 lat od wprowadzenia zmian, nie po 10.

$\mathrm{W}$ wyniku rewitalizacji stworzono przestrzeń publiczną sprzyjającą spotkaniom mieszkańców, a także organizowaniu wydarzeń kulturalnych. Mieszkańcy zaakceptowali te zmiany i zaczęli spędzać czas wolny w zrewitalizowanej przestrzeni. Jest to $\mathrm{w}$ chwili obecnej największy, bezpośrednio obserwowalny skutek rewitalizacji. Stworzenie estetycznej, atrakcyjnej przestrzeni publicznej „,starówki”, jak nazywały ją władze miast, na pewno sprzyja i będzie sprzyjać poczuciu dumy z faktu bycia mieszkańcem danego miasta, a także nowego zwyczaju spędzania czasu wolnego w nowo stworzonej, atrakcyjnej przestrzeni publicznej. W przyszłości być może te zmiany wpłyną na rozwój turystyki w mieście. Jednak w krótkim okresie trwające kilka lat remonty oraz ograniczenie ruchu samochodowego w centrach badanych miast nie wpłynęły pozytywnie na działających tam przedsiębiorców, nierzadko przyczyniając się do ich upadku lub znacznego pogorszenia opłacalności prowadzenia działalności gospodarczej. Zdaniem wielu osób właśnie te dwa czynniki doprowadziły do spadku konkurencyjności handlu w śródmieściu, a otworzenie galerii handlowych było tylko „ostatnim gwoździem do trumny”54.

Zachodzące przemiany zapoczątkowały w Kielcach dyskusję na temat potrzeby ożywienia śródmieścia oraz podnoszenia konkurencyjności handlu. Przedstawiciele władz miejskich zauważali, że aby robienie zakupów w śródmieściu było atrakcyjne dla klientów, konieczne jest wydłużenie godzin pracy sklepów oraz zmiana ich asortymentu na bardziej wyspecjalizowany, odróżniający ofertę sklepów w śródmieściu od oferty sklepów w galeriach handlowych. W długiej perspektywie ta dyskusja być może zapoczątkuje pozytywne zmiany w nastawieniu przedsiębiorców, a scenariusze ożywienia śródmieścia zostaną zrealizowane.

Zachodzące po 1999 r. przemiany miejskich przestrzeni konsumpcji zwiększyły zainteresowanie mieszkańców przestrzenią ich miasta, wpłynęły na wzrost zaangażowania społecznego i chęci wpływania na trwające procesy. I chociaż zaangażowane są nieliczne jednostki i raczej nie prognozowałabym masowego zaangażowania

54 Wywiad 9. 
mieszkańców, to w dłuższej perspektywie wykształcenie aktywnych grup mieszkańców chcących wpływać na zrównoważony rozwój swoich miast zwiększy przejrzystość decyzji podejmowanych w urzędach miast oraz przyczyni się do lepszego zarządzania jego rozwojem.

\section{Impact of revitalization of consumption spaces on the socio-economic development of Polish cities}

The aim of this paper is to describe and analyze the process of revitalization of markets and shopping streets of Polish cities after 1999 in order to answer the question on how revitalization affected the socio-economic development of Polish cities. Transformation of consumption space is analyzed on the example of two cities: Białystok and Kielce. As a result of revitalization, residents began to spend their free time in the modernized space. However, in the short term, the construction works lasting several years that reduced traffic in the city centers impacted negatively on businesses, often contributing to their collapse or significant deterioration of profitability. Transformation of urban consumption space have increased interest of city dwellers in local decision making process, and thus influenced the growth in social commitment and desire to participate in governing.

Keywords: revitalization, city, market square, shopping street, European Union, Kielce, Białystok

\section{L'impact de la revitalisation des lieux de consommation sur le développement socio-économique des villes polonaises}

Le but de cet article est de décrire et d'analyser le processus de revitalisation des marchés et des rues commerçantes des villes polonaises après 1999 afin de déterminer la façon dont cette revitalisation affecte le développement socio-économique des villes polonaises. La transformation des lieux de consommation est analysée sur l'exemple de deux villes: Białystok et Kielce. À la suite de la revitalisation, les résidents ont commencé à passer leur temps libre dans les lieux modernisés. Les travaux de construction pendant plusieurs années avaient abouti à la circulation réduite dans les centres-villes, ce qui a eu un impact négatif sur l'activité économique des entreprises, contribuant souvent à leur effondrement ou à leur faible 
rentabilité. La transformation des lieux de consommation urbaine a contribué à augmenter l'intérêt des citadins dans le processus de prise de décision au niveau local, et donc elle a influencé la croissance de l'engagement social et le désir de participer à gouverner.

Mots-clés: la revitalisation, la ville, le marché, la rue commerçante, l'Union européenne, Kielce, Białystok

\section{Влияние ревитализации пространств потребления на социально- -экономическое развитие польских городов}

Цель данной работы - описание и анализ процесса ревитализации рынков и торговых улиц польских городов после 1999 г. для того, чтобы дать ответ на вопрос, как ревитализация сказалась на их социально-экономическом развитии. Трансформация пространства потребления показана на примере двух городов: Белостока и Кельце. В результате ревитализации жители стали проводить свободное время в обновленном пространстве. Тем не менее, в краткосрочной перспективе, продолжающиеся несколько лет ремонтные работы и снижение автомобильного движения в центральной части городов имели негативное влияние на местные предприятия, часто приводя к их закрытью или значительному снижению их рентабельности. Преобразования городских пространств потребления повысили интерес жителей к своему городу и готовность принимать участье в решениях на местном уровне, таким образом, влияя на устойчивое развитие городов и способствуя лучшему управлению его развитием.

Ключевые слова: ревитализация, город, рыночная площадь, торговая улица, Европейский союз, Кельце, Белосток 
